\title{
Toksisitas Ekstrak Daun Srikaya (Annona squamosa Linn.) Terhadap Jamur Fusarium sp
}

\author{
Dewi Novianti \\ *e-mail: dewinovianti1980@gmail.com
Program Studi Biologi, Fakultas Matematika dan Ilmu Pengetahuan Alam
Universitas PGRI Palembang

\begin{abstract}
Research on the toxicity of Srikaya (Annona squamosa Linn.) Leaves extracts from Fusarium sp. This research was conducted in vitro with the aim to find out the toxicity of the soursop leaves methanol extract against Fusarium sp. The study used a completely randomized design with 6 treatments 5 replications. The methanol extract of srikaya leaves used were $0 \%, 2 \%, 4 \%, 6 \%, 8 \%$ and $10 \%$ concentrations. The results of analysis of variance showed that the treatment of srikaya leaves extract significantly affected the Fusarium sp. Srikaya leaf extract is toxic to the growth of Fusarium sp. The toxicity of srikaya leaves extract against Fusarium sp mushroom was directly proportional between the concentration of the treatment and the percentage of inhibition. The concentration of srikaya leaves extract as much as $2 \%$ has been toxic in inhibiting the growth of Fusarium sp.
\end{abstract}

Keywords: Srikaya leaves extract, Fusarium sp,fungus percentage inhibition

\begin{abstract}
ABSTRAK
Telah dilakukan penelitian Toksisitas Ekstrak Daun Srikaya (Annona squamosa Linn.) Terhadap Jamur Fusarium sp. Penelitian ini dilakukan secara in vitro dengan tujuan untuk menngetahui toksisitas ekstrak metanol daun srikaya terhadap jamur Fusarium sp penyebab layu kecambah pada tanaman. Penelitian menggunakan Rancangan Acak Lengkap dengan 6 perlakuan 5 kali ulangan. Ekstrak metanol daun srikaya yang dipakai yaitu konsentrasi $0 \%, 2 \%, 4 \%, 6 \%, 8 \%$ dan $10 \%$. Hasil analisis sidik ragam menunjukkan bahwa pemberian perlakuan ekstrak daun srikaya berpengaruh nyata terhadap jamur Fusarium sp. Ekstrak daun srikaya bersifat toksik terhadap pertumbuhan jamur Fusarium sp. Toksisitas ekstrak daun srikaya terhadap jamur Fusarium sp berbanding lurus antara konsentrasi perlakuan dengan persentase penghambatannya. Pada konsentrasi ekstrak daun srikaya sebanyak $2 \%$ sudah bersifat toksik dalam menghambat pertumbuhan Fusarium sp.
\end{abstract}

Kata Kunci: Ekstrak daun srikaya, jamur Fusarium sp, persentase penghambatan

\section{PENDAHULUAN}

Kerugian sektor pertanian Indonesia akibat serangan hama dan penyakit mencapai miliaran rupiah dan menurunkan produktivitas pertanian sampai 20 persen. Menghadapi seriusnya kendala tersebut, sebagian besar petani Indonesia menggunakan pestisida kimiawi. Upaya tersebut memberikan hasil yang cepat dan efektif. Kenyataan ini menyebabkan tingkat kepercayaan petani terhadap keampuhan pestisida kimiawi sangat tinggi. Sejalan dengan hal itu, promosi dari perusahan pembuat pestisida yang sangat gencar semakin 
meningkatkan ketergantungan petani terhadap pestisida kimiawi. Seperti halnya kebutuhan pupuk yang terus meningkat, kebutuhan pestisida juga memperlihatkan pertumbuhan tiap tahun. Rata-rata peningkatan total konsumsi pestisida per tahun mencapai 6,33 persen, namun pada kenyataannya di lapangan diperkirakan dapat mencapai lebih dari 10 Sampai 20 persen (Djunaedy, 2009). Suwahyono (2009), menyatakan bahwa penggunaan pestisida sintetik dapat membahayakan keselamatan hayati termasuk manusia dan keseimbangan ekosistem. Oleh sebab itu, saat ini metode pengendalian telah diarahkan pada pengendalian hayati/biopestisida.

Berdasarkan asalnya, biopestisida dapat dibedakan menjadi dua yakni pestisida nabati dan pestisida hayati. Pestisida nabati merupakan hasil ekstraksi bagian tertentu dari tanaman baik dari daun, buah, biji atau akar yang senyawa atau metabolit sekunder dan memiliki sifat racun terhadap hama dan penyakit tertentu. Pestisida nabati pada umumnya digunakan untuk mengendalikan hama (bersifat insektisidal) maupun penyakit (bersifat bakterisidal). Biopestisida yang terbuat dari bahan-bahan alam tidak meracuni tanaman dan mencemari lingkungan. Pemakaian ekstrak bahan alami secara terus menerus juga diyakini tak menimbulkan resisten pada hama, seperti yang biasa terjadi pada pestisida sintetis. Beberapa jenis tanaman yang mampu mengendalikan hama seperti famili Meliaceae seperti nimbi dan Aglaia, famili Anonaceae seperti biji srikaya dan biji sirsak (Djunaedy, 2009).

Jamur Fusarium sp merupakan salah satu jenis jamur yang sangat penting untuk diketahui dalam melaksanakan budidaya tanaman. Jamur jenis ini, menjadi inang demikian banyak jenis tanaman, mulai dari tanaman yang berarti strategis sampai tanaman pagar di kebun petani. Jamur ini mempunyai variasi spesies yang tinggi, yaitu sekitar 100 jenis dan menyebabkan kerusakan secara luas dalam waktu singkat dengan intensitas serangan mencapai 35\% (Sudantha,2010). Jamur Fusarium sp adalah salah satu jenis patogen tular tanah yang mematikan, karena patogen ini mempunyai strain yang dapat dorman selama 30 (tiga puluh) tahun sebelum melanjutkan virulensi dan menginfeksi tanaman. Fusarium sp tergolong kedalam kingdom: Mycetae, divisi: Mycota, subdivisi: Deuteromycotina, klas Hypomycetes, ordo Hyphales(Moniliales), family: Tuberculariaceae, dan genus Fusarium. Jamur ini bersekat terutama terdapat di dalam sel, khususnya di dalam pembuluh kayu, membentuk miselium yang terdapat diantara sel-sel, yaitu dalam kulit dan di jaringan parenkim di dekat tempat terjadinya infeksi. Jamur Fusarium sp merupakan penyebab penyakit layu dan busuk batang pada berbagai jenis tanaman pangan, hortikultura dan perkebunan. Inang dari patogen ini adalah sayuran, bawang, kentang, tomat, kubis, lobak, petsai, sawi, temu-temuan, semangka, melon, pepaya, salak, krisan, anggrek, kacang panjang, cabai, ketimun, jambu biji, dan jahe. Tanaman lain yang diketahui menjadi inang patogen ini adalah kelapa sawit, kelapa, lada, vanili, dan kapas (Semangun 2004 dalam Juniawan, 2015).

Daun srikaya mengandung Lanonaine yang memiliki kemampuan antimikroba dan hama arthropoda pengangu tanaman . Hasil penelitian Purwita et al (2013) bahwa ekstrak metanol daun srikaya (Annona squamosa) dapat digunakan sebagai antioksidan dan antijamur terhadap Fusarium sp. Kandungan senyawa antijamur yang terdapat pada daun srikaya yaitu annonain, saponin, flavonoid dan tannin (Purwita et al 2013). Annonain merupakan senyawa golongan alkaloid yang terdapat pada daun srikaya. 
Aktifitas fisiologinya bersifat racun dan memiliki rasa yang pahit. Penggunaan ekstrak daun srikaya dapat menghambat pertumbuhanFusarium sp pada konsentrasi $6,5 \%$ dengan persentase penghambatan $60 \%$ dengan menggunakan uji fitokimia. Annonain merupakan senyawa golongan alkaloid yang terdapat pada daun srikaya. Aktifitas fisiologinya bersifat racun dan memiliki rasa yang pahit. Daun srikaya memiliki potensi sebagai anti jamur $C$. acutatum penyebab penyakit antraknos pada tanaman cabai besar (Capsicum annum L ). Mekanisme penghambatan senyawa-senyawa yang terkandung dalam suatu bahan terhadap fungi yaitu dengan cara: merusak integritas membran sel fungi sehingga permeabilitas sel terganggu dan akhirnya sel akan hancur; serta mengganggu sintesis protein. Secara in vitro campuran ekstrak daun sirsak (Annona muricata L), daun kirinyuh (Chromolaena odorata L) dan rimpang lengkuas (Alpinia galanga L) dengan konsentrasi $1 \%$ dapat menghambat pertumbuhan koloni Colletotrichum acutatum pada masa inkubasi 7 hari sebesar 66,19\%, sedangkan pada masa inkubasi 14 hari sebesar 69,94\% (Hodiyah et al 2017). Berdasarkan uraian di atas maka dilakukanlah uji toksisitas ekstrak daun srikaya terhadap jamur Fusarium sp.

\section{BAHAN DAN METODE}

Penelitian menggunakan RAL 6 perlakuan 5 kali ulangan. Perlakuan ekstrak daun srikaya yaitu: $\mathrm{Po}=0 \% ; \mathrm{P} 1=$ $2 \% ; \mathrm{P} 3=4 \% ; \mathrm{P} 4=8 \%$; dan $\mathrm{P} 5=10 \%$. Alat yang digunakan yaitu: autoclave, beaker glass, blender, bunsen, cawan petri, corong, erlenmeyer, gunting, haemocytometer, jangka sorong, jarum ose, kamera, mikroskop, kertas cakram (diameter=0,6 cm), pipet tetes, pipet volume, pisau, spatula, tabung reaksi, dan timbangan analitik. Bahan yang digunakan adalah: agar-agar, alkohol, aluminium foil, aquades, daun srikaya, kapas, kertas label, kertas saring, media PDA, metanol, isolat jamur Fusarium sp, dan plastik wrap. Alat-alat yang digunakan dalam kondisi steril. Jarum Fusarium sp yang akan digunakan dalam bentuk suspensi dengan kepadatan $10^{8}$ konidia/ml. Ekstrak daun srikaya yang telah dibuat dengan berbagai konsentrasi perlakuan dimasukkan ke dalam cawan petri kemudian ditambahkan larutan media PDA, dibiarkan hingga dingin dan mengeras, media perlakuan siap digunakan. Ekstrak daun srikaya dibuat dengan metode maserasi menggunakan metanol. Kertas cakram yang telah diberi suspensi Fusarium sp diletakkan di tengah-tengah media perlakuan, lalu diinkubasi selama satu minggu pada suhu ruang. Setelah satu minggu diameter koloni jamur Fusarium sp dengan menggunakan jangka sorong dan dihitung persentase penghambatannya (Noveriza dan Miftakhuromah, 2010). Data dianalisa menggunakan analisis sidik ragam.

\section{HASIL DAN PEMBAHASAN}

Hasil analisis ansira penghambatan toksisitas ekstrak daun srikaya terhadap jamur Fusarium sp didapatkan bahwa perlakuan ekstrak daun srikaya berpengaruh nyata terhadap persentase penghambatan Fusarium sp. Persentase penghambatan toksisitas ekstrak daun srikaya terhadap jamur Fusarium dapat dilihat pada Gambar 1 dan 2 di bawah ini. 


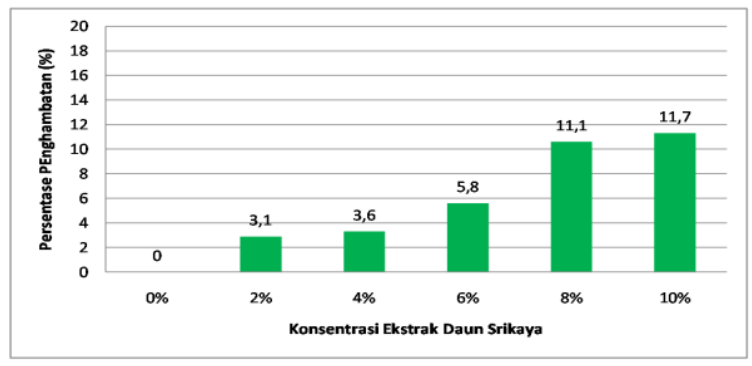

Gambar 1. Persentase Penghambatan Toksisitas Ekstrak Daun Srikaya Terhadap Jamur Fusarium sp

Pada Gambar 1, semakin tinggi konsentrasi ekstrak daun srikaya maka semakin tinggi persentase penghambatan koloni jamur Fusarium sp. Pemberian ekstrak daun srikaya sebanyak $0 \%$ tidak terjadi penghambatan pertumbuhan jamur Fusarium sp. Pada perlakuan pemberian ekstrak $2 \%$ didapatkan persentase penghambatannya $3,1 \%$; perlakuan pemberian ekstrak 4\% didapatkan persentase penghambatannya $3,6 \%$; perlakuan pemberian ekstrak $6 \%$ didapatkan persentase penghambatannya $5,8 \%$; perlakuan pemberian ekstrak $8 \%$ didapatkan persentase penghambatannya $11,1 \%$; dan perlakuan pemberian ekstrak $10 \%$ didapatkan persentase penghambatannya $11,7 \%$. Pada perlakuan 0\% (kontrol), Fusarium sp ini ditanam pada cawan petri yang hanya berisi media PDA tanpa pemberian ekstrak daun srikaya hanya menggunakan aquadest steril sehingga media PDA tersebut tidak mengandung senyawa antijamur.
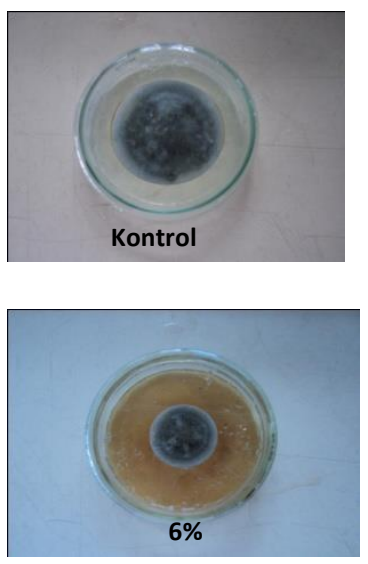
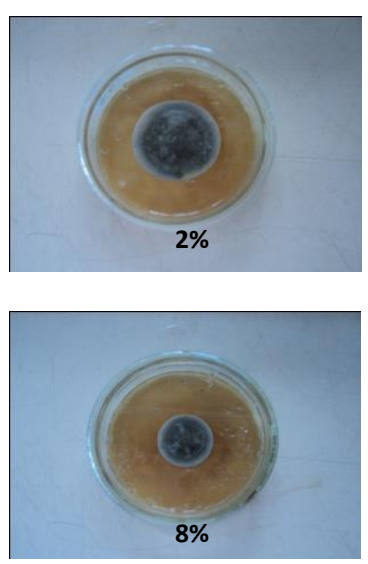
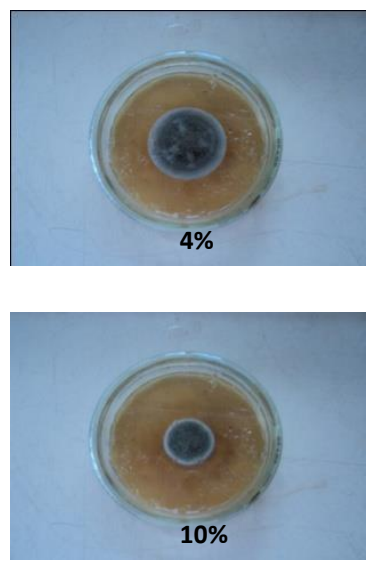

Gambar 2. Toksisitas Ekstrak Daun Srikaya Terhadap Pertumbuhan Koloni Jamur Fusarium sp pada Hari ke-7

Pada Gambar 2, hasil penelitian menunjukkan bahwa semakin tinggi konsentrasi ekstrak daun srikaya maka semakin tinggi penghambatan diameter koloni jamur $F$. oxysporum. Artinya, pada konsentrasi yang tertinggi maka pertumbuhan koloni jamur semakin terhambat. Hasil penelitian Dotulung et al (2019), fungisida nabati ekstrak daun srikaya paling efektif persentase penghambatannya karena daya toksisitasnya yang tinggi tersebut dapat menghambat pertumbuhan koloni jamur $F$. oxysporum lebih tinggi dibandingkan 
dengan daun pepaya dan jeruk purut). Penghambatan ekstrak daun srikaya terhadap jamur $F$. oxysporum diduga terjadi oleh kemampuan penghambatan senyawa lektin, yaitu golongan senyawa protein- karbohidrat yang tersebar luas di alam yang salah satunya terkandung pada daun srikaya (Gomez et al 2012). Mekanismenya yaitu penghambatan germinasi spora. Gangguan ini terjadi karena adanya ergasol dalam sel fungi, ini adalah komponen sterol yang sangat penting dan sangat mudah diserang oleh antibiotik turunan polien. Penghambatan biosintesis ergosterol dalam sel fungi, merupakan mekanisme yang disebabkan oleh senyawa turunan imidazol karena mampu menimbulkan ketidakaturan membran sitoplasma fungi dengan cara mengubah permeabilitas membran dan fungsi membran dalam proses pengangkutan senyawa-senyawa esensi yang dapat menyebabkan ketidakseimbangan metabolik sehingga menghambat pertumbuhan atau menimbulkan kematian sel fungi. Wati (2012) juga memberikan hasil bahwa flavonoid yang merupakan salah satu senyawa yang terkandung dalam filtrat daun alang-alang mampu menghambat pertumbuhan jamur Trichoderma sp sebesar $1,5 \mathrm{~cm}$ pada konsentrasi $40 \%$. Dinding sel fungi terganggu karena adanya sintesis kitin oleh lektin. Hasil analisis fitokimia ekstrak daun sirsak mengandung senyawa alkaloid, glikosid, flavonoid, tanin, karbohidrat, fenol dan saponin. Ekstrak daun srikaya memiliki kemampuan menghambat pertumbuhan jamur Fusarium solani. Pada konsentrasi $2 \mathrm{mg} / \mathrm{ml}$ ekstrak daun srikaya menghasilkan persentase penghambatan 97,92\% (Kalidindi et al., 2015). Kedua simplisia tersebut menunjukkan karakteristik simplisia dan pola kromatogram KLT ekstrak yang mirip. Suatu senyawa golongan triterpenoid telah berhasil diisolasi dari ekstrak nheksana simplisia 2. Isolat tersebut tidak memiliki ikatan rangkap terkonjugasi dan memiliki gugus $\mathrm{O}-\mathrm{H}, \mathrm{C}-\mathrm{H}$, dan $\mathrm{C}=\mathrm{C}$ (Kusmardiyani et al., 2012).

Secara morfologi Fusarium spp. dapat dikenali berdasarkan bentuk makrokonidium, struktur konidiofor mikrokonidium, panjang fialid, pembentukan dan posisi klamidospora. Meskipun pengamatan morfologi tidak cukup untuk identifikasi lengkap, tapi banyak informasi yang dapat diperoleh saat biakan di medium kultur. Hasil pengamatan bentuk makrokonidium dan mikrokonidium menunjukkan adanya perbedaan spesifik antara $F$. oxysporum, $F$. solani, $F$. verticillioides, $T$. polyzona dan $C$. rosea. $T$. polyzona merupakan cendawan tanah yang berasal dari rizosfer tanaman pisang kultivar Nangka dan $C$. rosea merupakan isolat yang berasal dari batang tanaman pisang kultivar Ambon Kuning. Kedua cendawan ini mempunyai karakter morfologi yang berbeda dengan Fusarium spp., dimana keduanya tidak memiliki makro dan mikrokonidia. $T$. polyzona mempunyai konidia dengan ukuran yang sangat kecil dibanding dengan mikrokonidia Fusarium spp. Ciri khas dari $F$. oxysporum mempunyai makrokonidium yang sedikit bengkok dengan ujung runcing, terdiri atas 3-4 sekat. Mikrokonidium yang berbentuk oval atau seperti ginjal, tanpa sekat dan terbentuk pada ujung fialid yang bertangkai pendek. Sedangkan $F$. solani mempunyai makrokonidium yang besar dan tumpul terdiri dari 3-4 sekat, dengan mikrokonidium yang berbentuk oval (dengan atau tanpa sekat) dan terbentuk pada ujung tangkai fialid yang panjang. $F$. oxysporum dan $F$. solani mempunyai klamidospora yang tersusun dalam satu rantai atau terdapat pada ujung dan tengah hifa. F.verticilliodes mempunyai makrokonidium yang lurus, panjang dan langsing, dengan sekat 3-5. Mikrokonidium berbentuk oval dan tanpa sekat. $F$. verticilliodes tidak mempunyai klamidospora (Sari et al., 2017). Hasil 
Penelitian Shamsi and Hosen (2016), jamur Fusarium sp dikenali cirinya koloni berwarna putih, jika tua sampai kuning tergantung umur kultur, konidiospora pendek, mempunyai hialin, berbentuk elips, ukuran $22-27 \times 14-18$ $\mu \mathrm{m}$.

\section{KESIMPULAN}

Ekstrak daun srikaya sudah bersifat toksik pada konsentrasi 2\% yang menyebabkan penghambatan pertumbuhan jamur Fusarium sp sebesar $3,1 \%$. Peningkatan konsentrasi ekstrak daun srikaya berbanding lurus dengan hasil persentase penghambatan pertumbuhan jamur Fusarium sp.

\section{DAFTAR PUSTAKA}

Djunaedy, A. (2009). Biopestisida Sebagai Pengendali Organisme Pengganggu Tanaman (OPT) yang Ramah Lingkungan. Embryo 6(1): 88-95.

Dotulung, G., S, Umboh, and J, Pelealu. (2019). Uji Toksisitas Beberapa Fungisida Nabati terhadap Penyakit Layu Fusarium (Fusarium oxysporum) pada Tanaman Kentang (Solanum tuberosum L.) secara In Vitro. Bioslogos 9(2): 92-101.

Gomez, BS., Siquiera., RCC, Maia., V, Giampaoli., EH, Teixeiras., FVS, Arrudas., KS, Nascimento., CMS, Motta., BS Cavada., and ALF, Porto. (2012) Antifungal Activity of Lectins Against Yeast of Vaginal Secretion. Brazilian Journal of Microbiology: 770-778.

Hodiyah, I., E, Hartini., A, Amilin., and MF, Yusup. (2017). Daya Hambat Ekstrak Daun Sirsak, Kirinyuh, dan Rimpang Lengkuas Terhadap Pertumbuhan
Colletotrichum acutatum Jurnal Agro. 4(2): 80-89.

Juniawan. (2015). Mengenal Jamur Fusarium oxysporum. BBPP Ketindan.

Https://bbppketindan.bppsdmp.pert anian.go.id/. Diakses 10 September 2019.

Kalidindi, N., NV, Thimmaiah., NV , Jagadeesh., R, Nandeep., S, Swetha., and B, Kalidindi. (2015). Antifungal and antioxidant activities of organic and aqueous extracts of Annona squamosa Linn. Leaves. Journal of Food and Drug Analysis. 23: 795-802.

Kusmardiyani, S., F, Wandasari., K.R, Wirasutisna. (2012). Telaah Fitokimia Daun Srikaya (Annona squamosa L.) yang Berasal dari Dua Lokasi Tumbuh. Acta Pharmaceutica Indonesia. 37(1): 913.

Noveriza, R dan Miftakhuromah. (2010). Efektivitas Ekstrak Metanol Daun Salam (Eugenia polyantha) dan Daun Jeruk Purut (Cytrus histrix) Sebagai Antijamur pada Pertumbuhan Fusarium oxysporum. Jurnal Littri 16(1):6-11.

Purwita, A., Indah, NK, Indah., and G, Trimulyono. (2013). Penggunaan Ekstrak Daun Srikaya (Annona aquamosa) sebagai Pengendali Jamur Fusarium oxyporum secara In Vitro. LenteraBio. 2(2): 179183. 
Sari, W., S, Wiyono., A, Nurmansyah,., A, Munif., and R, Poerwanto. (2017). Keanekaragaman dan Patogenisitas Fusarium spp. Asal Beberapa Kultivar Pisang. Jurnal Fitopatologi Indonesia 13(6): 216228.

Shamsi, S and S, Hosen. (2016). Mycoflora Associated with Fruit Rot of Custard Apple (Annona squamosa L.). Bangladesh J. Sci. Res. 29(2): 173-176,

Suwahyono, U. (2009). Biopestisida. PT. Niaga Swadaya. Jakarta.

Wati, DK. (2012). Pengaruh Pemberian Filtrat Daun Alang-Alang (Imperata cylindrica L.) terhadap Pertumbuhan Miselium Jamur Trichoderma sp yang Hidup pada Media Tanam Jamur Tiram Putih (Pleurotus ostreatus). LenteraBio. 1(2): 93-98 